medical science, marine science, industrial science and technology, and socio-economy.

The Ministry has responsibility for such agencies as the Standards and Industrial Research Institute, the Tun Ismail Atomic Research Centre, the Chemistry Department and the Wildlife National Parks. The Rubber Research Institute, which is a big and successful institute dealing with development of the most important economic commodity of the country is not under this Ministry but under the Ministry of Primary Industries.

\section{Singapore}

Science policy guidelines in Singapore are drawn up by the Ministry for Science and Technology, a small ministry which also runs some service departments and has responsibility for promoting public appreciation of science and technology. For the last purpose an impressive Science Centre has been established, and a major part of the activities of the Science Council, an advisory body composed of the nation's scientific and technical leaders, is devoted to such popular television programmes as the science quiz. With the exception of the recent establishment of the Applied Research Corporation, however, the Ministry is not directly concerned with research and development activities. For example, the important Singapore Institute of Standards and Industrial Research is under the Ministry of Finance, and research in universities is supported mainly by the Ministry of Education.

\section{Thailand}

Thailand has no single organisation on science and technology of equivalent status to a ministry, but has the National Research Council (NRC) with the responsibility of advising the government on natural and social science policy, identifying and supporting research topics of high priority. It has five national committees covering the areas of physical science and mathematics, medical science, chemical and pharmaceutical science, agriculture and biology, and engineering and industrial research, and another five national committees for social science and humanities.

Formulation of Thai science and technology policy with special reference to economic development is also the task of a small division of the National Economic and Social Development Board. Having more than one agency in a small country dealing with science policy can be a source of potential conflicts, which fortunately have not materialised so far. Recently the NRC has recommended to the government that a Ministry of Science and Tech-

\title{
Regional co-operative programmes
}

A NUMBER of regional programmes in science and technology have been set up through the agreements among Southeast Asian countries. The following are a few of the important ones:

Southeast Asian Ministers of Education Organisation (SEAMEO) programmes involve the support of centres of excellence in various fields in the ASEAN countries. Of the six regional centres, five are concerned with science and technology. These are Regional Centre for Tropical Biology (BIOTROP) located in Bogor, Indonesia; Regional Centre for Educational Innovation and Technology (INNOTECH) in Quezon City, Philippines; Regional Centre for Graduate Study and Research in Agriculture (SEARCA) in Los Banos, Philippines; Regional Centre for Education in Science and Mathematics (RECSAM) in P e n a n g, Malaysia; and Regional Project for Tropical Medicine and Public Health (TROPMED), which is a network of national centres with the head office in Bangkok, Thailand.

Ministerial Conferences for the Economic Development of Southeast Asia, usually attended by ministers of foreign affairs of member countries, which include Japan, Australia and New Zealand in addition to the ASEAN countries, support various programmes in science and technology. Important bodies in the group are Southeast Asian Fisheries Development Centre (SEAFDEC), Southeast Asian Agency for Regional

nology be created with the main task of formulating overall science and technology policy, and conducting and supporting research and other activities in various fields. However, rather than accepting the proposal, the government will probably modify the structure of the Ministry of Industry to encompass the task of the proposed new ministry as well.

\section{Conclusions}

Science and technology in ASEAN countries needs much more planning and stimulus both from local and outside sources in order to reach a level of development comparable to, say, South Korea or Australia. For example, a mechanism is lacking whereby the results of locally supported research can be evaluated effectively. This may require the consultation of experts from outside the country, who can give critical opinions without bias. Planning of future programmes can also be more effective with such consultation.
Transport and Communication Development (SEATAC) and Southeast Asian Medical and Health Organization (SEAMHO).

ASEAN has a Bureau of Science and Technology and Permanent Committees (PC) on various aspects of science and technology, namely, PC on Science and Technology, PC on Food and Agriculture, PC on Communication/Air Traffic Services and Meteorology, PC on Commerce and Industry and PC on Land Transportation and Telecommunications. An important project of the PC on Science and Technology is on soybean and other protein-rich foods funded with an aid of 2.5 million Australian dollars granted by Australia.

The Regional Office for Science and Technology for Southeast Asia of UNESCO actively supports various co-operative programmes. In the past few years with the support of UNESCO and other agencies, regional networks have been developed in specific areas of research, involving a number of national institutions or bodies linked together to facilitate regional communication and co-operation. The headquarters of the Regional Networks for Microbiology and for Chemistry of Natural Products are located in Bangkok, and for Geosciences in Seoul. A regional programme for postgradute training and research in marine sciences for Southeast Asia, has also been formed with the support of UNESCO, UNDP, SEAFDEC and the host governments.

These and other problems in research and development would require more collaboration with international bodies. Academic societies would be potential initiators of such collaboration. The proposed formation of International Chemical Society with key objectives of providing scientific aids to developing countries is interesting in this respect. Existing bodies such as Federation of Asian and Oceanian Biochemists can also provide some help. The main effort must, however, come from the governments of the ASEAN countries themselves since they are by far the largest sponsors of research and development. That international cooperation on the government level is an important factor has been realised on many occasions, including the 1975 Meeting of Directors of National Councils for Science Policy and Research in Asia and Oceania held in Kuala Lumpur. Much more effort is needed still to translate the plans into action. 